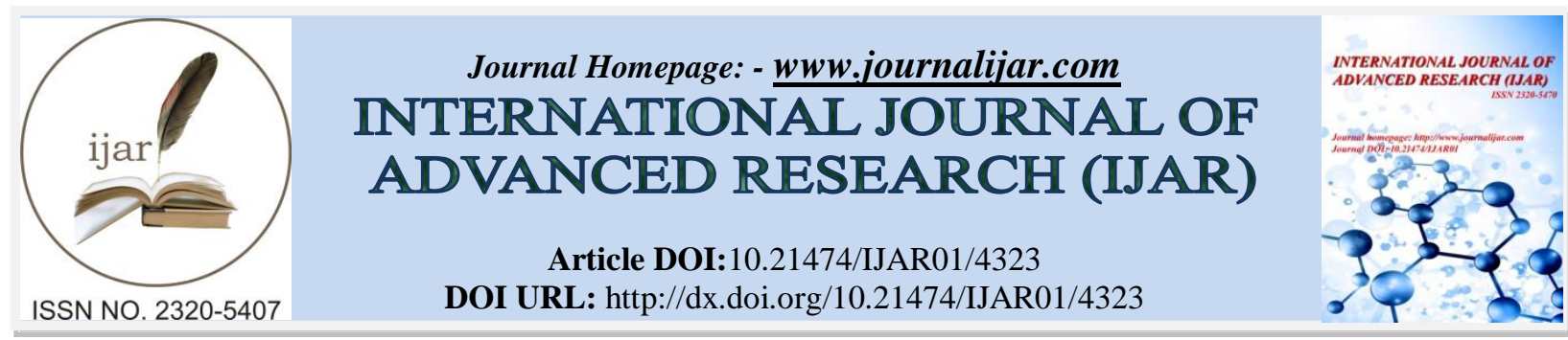

RESEARCH ARTICLE

\title{
DIFFERENTIATION OF HUMAN UMBILICAL CORD MESENCHYMAL STEM CELLS INTO INSULIN PRODUCING BETA CELLS FOR DIABETIC THERAPY.
}

\author{
Keerthi Konda Juturu ${ }^{1}$, Vasundhara Kamineni ${ }^{2}$, Ravi Shankar ${ }^{3}$, Jayashankar Errukumbattu ${ }^{3}$, Ramamurti \\ Tanikella $^{3}$,Vijaya Lakshmi Ayyala ${ }^{3}$, Sukumar Pujari ${ }^{4}$ and Hasan Qurratulian ${ }^{1}$ \\ 1. Department of Genetics and Molecular Medicine. \\ 2. Department of Obstetrics and Gynecology. \\ 3. Department of Microbiology, Department of Pathology,Department of Biochemistry, Kamineni Hospitals, \\ L.B.Nagar, Hyderabad. \\ 4. Indian Immunologicals Limited, Gachibowli, Hyderabad.
}

\section{Manuscript Info}

Manuscript History

Received: 24 March 2017

Final Accepted: 29 April 2017

Published: May 2017

Key words:-

Umbilical Cord tissue; Mesenchymal

stem cells; pancreatic beta cells;

Flowcytometry; Differentiation.

\section{Abstract}

Aim: The aim of the present study was to evaluate the potential of using human umbilical cord tissue as a source of mesenchymal stem cells to differentiate into functional pancreatic $\beta$-cells.

Method: Umbilical Cord Mesenchymal Stem Cells (MSCs), which have a low risk of immune rejection, were isolated, cultured in-vitro and characterized by Flowcytometry and immunocytochemistry. Further they were differentiated successfully in-vitro into functional pancreatic $\beta$-cells using H-DMEM ( $25 \mathrm{mM}$ glucose/L) supplemented with $\beta$-Mercaptoethanol $(0.1 \mathrm{mM} / \mathrm{L})$, b-Fibroblast growth factor $(10$ $\mu \mathrm{g} / \mathrm{L})$, Taurine $(10 \mathrm{mM} / \mathrm{L})$ and Nicotinamide $(10 \mathrm{mM} / \mathrm{L})$.

Results: Umbilical cord sample of $8 \mathrm{~cm}$ length yielded $1.5^{*} 10^{5} \pm$ $0.5^{*} 10^{5}$ cells after enzymatic digestion. These were passaged to confluence and were found by Flowcytometry to be $\mathrm{CD}-73^{+}, \mathrm{CD}-90^{+}$, CD- $105^{+}$, Vimentin ${ }^{+}, \mathrm{CD}-34^{-}, \mathrm{CD}-45^{-}$and HLA-DR ${ }^{-}$indicating that 95\% of cells were MSCs. These were differentiated for 25 days and $20 \%$ stained positive for Dithizone, which is a specific marker for pancreatic beta cells. Insulin secreted in the medium was evaluated with and without glucose stimulation.

Conclusion: It is evident from this work that Umbilical cord tissue which is easily and ethically available is suitable to isolate MSCs, which have a potential to differentiate into insulin secreting $\beta$-cell invitro. These differentiated cells can be placed in-vivo either by Edmonton protocol into the pancreatic duct or embedded in omentum for managing both Type- 1 and Type-2 Diabetes Mellitus. This is a promising treatment option, especially since recent literature proposes that pancreatic $\beta$-cell apoptosis is the underlying cause of both these pathologies.

Copy Right, IJAR, 2017,. All rights reserved.

\section{Introduction:-}

Diabetes is the major non-communicable disease of the decade with estimated 422 million individuals diagnosed globally, according to World Health Organization (WHO) 2016. Pancreatic $\beta$-cells are the predominant insulin 
producing cell types within the Islets of Langerhans and insulin is the primary hormone which regulates carbohydrate and fat metabolism, the absence or dysfunction of it results in DM [1,2]. According to a recent paper $\beta$-cell apoptosis is the common underlying cause of both Type-1 Diabetes (T1D) and Type-2 Diabetes (T2D) [3].

The current therapy of Diabetes includes oral medication or exogenous insulin replacement and regular monitoring [4]. Although pancreatic allotransplantation is an alternative to conventional insulin therapy, it is not considered at present as an accepted standard of care due to the lifelong requirement of immunosuppressive therapy and scarcity of suitable healthy organs for the millions suffering with this disease [5, 6]. To overcome these obstacles cell based regenerative therapy would be a suitable alternative in which stem cells could be differentiated into insulin producing $\beta$-cells $[7,8,9]$ and can be transplanted in a patient either by (i) invasive intra portal transplantation $[6,10]$ or (ii) minimally invasive encapsulation [2] or by (iii) seeding in the omentum [11].

Mesenchymal stem cells (MSCs) were identified for the first time from bone marrow and were subsequently successfully isolated from several tissues and irrespective of its origin exhibited the same phenotypic properties [12]. MSCs have specific characteristics such as plastic adherence and exhibit certain specific cell surface markers like CD-105, CD-90 and CD-73[13, 14]. They have a capacity of self renewing and have the ability to differentiate into Adipogenic, Chondrogenic and Osteogenic cell lineages $[15,16]$.

In the present study umbilical cord (UC) tissue was selected as a source for MSCs, since sampling is non invasive, abundantly available and considered as a clinically waste material and discarded, hence very few ethical controversies are involved in it [17]. MSCs are present in the UC within the extracellular matrix of the Wharton's jelly, where a number of growth factors exist [18].

Aim:-

The aim of the present study was to evaluate the potential of using human umbilical cord tissue as a source of mesenchymal stem cells to differentiate into functional pancreatic $\beta$-cells and use them in the treatment of both Type-1 and Type-2 DM.

\section{Materials and Methodology:-} Sample Collection:-

With prior informed consent as approved by the Hospital Institutional Ethical and Stem cell Committee, Human umbilical cord (HUC) tissues were collected after lower segment caesarean section (LSCS) or normal vaginal delivery and transported to the laboratory in sterile normal saline within 30 minutes.

\section{Isolation and Expansion of MSCs from HUC:-}

HUC samples were processed within an hour after collection in a laminar air flow cabinet. Umbilical cord was opened lengthwise, blood vessels were dissected and the remaining tissue was scraped and minced mechanically in a sterile petri-dish. This was transferred to a $50 \mathrm{ml}$ centrifuge tube along with normal saline digested enzymatically with Collagenase-II (50-200 U/ml, Gibco USA), at $37^{\circ} \mathrm{C}$ in $5 \% \mathrm{CO}_{2}$ incubator for 35 minutes. The digested tissue was collected and centrifuged at 1500 RPM for 15 minutes. Cell pellet obtained was initiated in a T-25 flask and provided with Low Glucose-Dulbecco's Modified Eagles Medium (L-DMEM 4.5 mM glucose/L), streptomycin $0.1 \mathrm{mg} / \mathrm{ml}$ and $10 \%$ FBS for cell growth and attachment. Every third day medium was replaced with fresh medium and the cells were passaged when they reached $70-80 \%$ confluence by treating with $0.25 \%$ Trypsin-EDTA and were split and reinitiated in new flasks with a cell count of $2000 \mathrm{cells} / \mathrm{cm}^{2}$.

\section{Cell count and Viability:-}

Growth curve was plotted by culturing the cells in a 12 well plate. In which cells were harvested on a day to day basis and cell count was performed to establish the log phase of the cells. Cell count was established using the Neubar chamber: $10 \mu \mathrm{l}$ of a cell suspension of unknown concentration was mixed with equal volume of $0.4 \%$ Tryphan Blue solution, incubated 2-5 minutes at room temperature. Evaluated under 10X magnification in a binocular inverted microscope (Nikon TS100, Japan).

The cell concentration was then calculated as follows: Cell concentration (in cells $/ \mathrm{ml}$ ) $=$ average count $\times 2 \times 10,000$ $\mathrm{x}$ dilution factor of original cells. 


\section{Karyotyping:-}

Karyotyping was performed on the cultured cells after each passage toanalyze numerical/structural changes in chromosomes if any. Metaphase images obtained in 100X and analyzed using DSS spectral imaging software system. International System for Human Chromosome Nomenclature (ISCN) 2013 used for analysis of karyotypes.

\section{Flowcytometry:-}

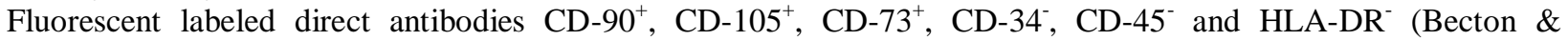
Dickinson (BD) Biosciences, USA) were added to the cells from P1 passage, which were dislodged using $0.25 \%$ Trypsin-EDTA and resuspended in Phosphate Buffer Saline (PBS) and incubated for 30 minutes at room temperature. The labeled cells were analyzed by BD-FACS Caliber (BD Biosciences, USA) by the method of Feisst et.al (2014).

\section{Immunocytochemistry:-}

Immunocytochemistry was performed using Vimentin antibody on isolated MSCs based on standard basic protocol of Wang et.al (2011).

\section{Differentiation:-}

MSCs were differentiated into insulin producing $\beta$-cells with High Glucose-Dulbecco's Modified Eagles Medium (H-DMEM 25mM Glucose/L) supplemented with $\beta$-Mercaptoethanol (0.1 mM, Himedia), b-Fibroblast growth factor $\left(10 \mu \mathrm{g} / \mathrm{L}\right.$, Gibco USA), Taurine $\left(10 \mathrm{mM} / \mathrm{L}\right.$, Himedia) and Nicotinamide $\left(10 \mathrm{mM} / \mathrm{L}\right.$, HiMedia) and incubated at $37^{\circ} \mathrm{C}$ in a $5 \% \mathrm{CO}_{2}$ incubator.

\section{Dithizone staining:-}

Diphenylthiocarbazone, Dithizone (DTZ, Sigma) is a zinc-chelating substance which is used for identification of insulin granules in pancreatic $\beta$-cells. DTZ stock solution $(10 \mathrm{mg} / \mathrm{ml})$ was prepared in Dimethylsulfoxide (DMSO) and stored at $-20^{\circ} \mathrm{C}$. Dithizone working solution was obtained by adding $10 \mu \mathrm{l}$ of the stock solution to $1 \mathrm{ml}$ of the culture medium, followed by filtration through a 0.2 micron filter. Differentiated HUMSCs were incubated with the staining solution at $37^{\circ} \mathrm{C}$ for 20 minutes and then examined [19].

\section{ELISA:-}

The Human Insulin Enzyme-Linked Immunosorbent Assay (ELISA) is an in vitro enzyme-linked Immunosorbent assay for the quantitative measurement of human Insulin in serum, plasma, cell culture supernatants or in urine. In our study ELISA was performed for quantitative estimation of insulin in cell culture supernatant with $(50 \mathrm{mM}$ glucose/L) and without glucose stimulation [20].

\section{Results:-}

A total of $26 \mathrm{HUC}$ tissues were collected out of which six were from normal vaginal delivery remaining 20 were after LSCS. Approximately $8 \mathrm{~cm}$ size cord was processed and MSCs were successfully isolated from 16 samples which were all obtained after LSCS. Cell attachment started on day four, small colonies observed on day six or seven, large colonies were observed by $12^{\text {th }}$ day which were considered as $\mathrm{P}^{0}$ population. Mean cell count observed was $1.5^{*} 10^{5} \pm 0.5 * 10^{5}$, cell viability was found to be $98 \%$ (Figure $1 . A, 1 . B$ ).

Two samples were used to establish the growth kinetics of MSCs, which showed that cells actively divided till $5^{\text {th }}$ day when the initial cell count was 2000 cells $/ \mathrm{cm}^{2}$ and later reached a growth plateau (Figure 2A). Numerical and structural abnormalities were not found in the chromosomes till the $5^{\text {th }}$ passage (Figure $2 \mathrm{~B}$ ).

Flow Cytometry analysis was performed on two samples on $\mathrm{P}^{2}$ population which showed that $95 \%$ cells expressed CD90, CD105, 80\% cells expressed CD73, none of them expressed CD34, CD45 and 20\% cells expressed HLA-DR (Figure 3). Immunocytochemistry was performed on one sample for Vimentin antibody in which all the cells showed positive staining (Figure 1.D, E).

4 samples were used for Differentiation in which one sample got contaminated and remaining samples were further processed for differentiation with the above mentioned growth factors. After 25 days of incubation cells stained positive for Dithizone (Figure 1). Amount of insulin released was measured by ELISA and was found to be four-fold higher when stimulated $(8 \mathrm{IU} / \mathrm{ml})$ compared with unstimulated $(2 \mathrm{IU} / \mathrm{ml})$. 


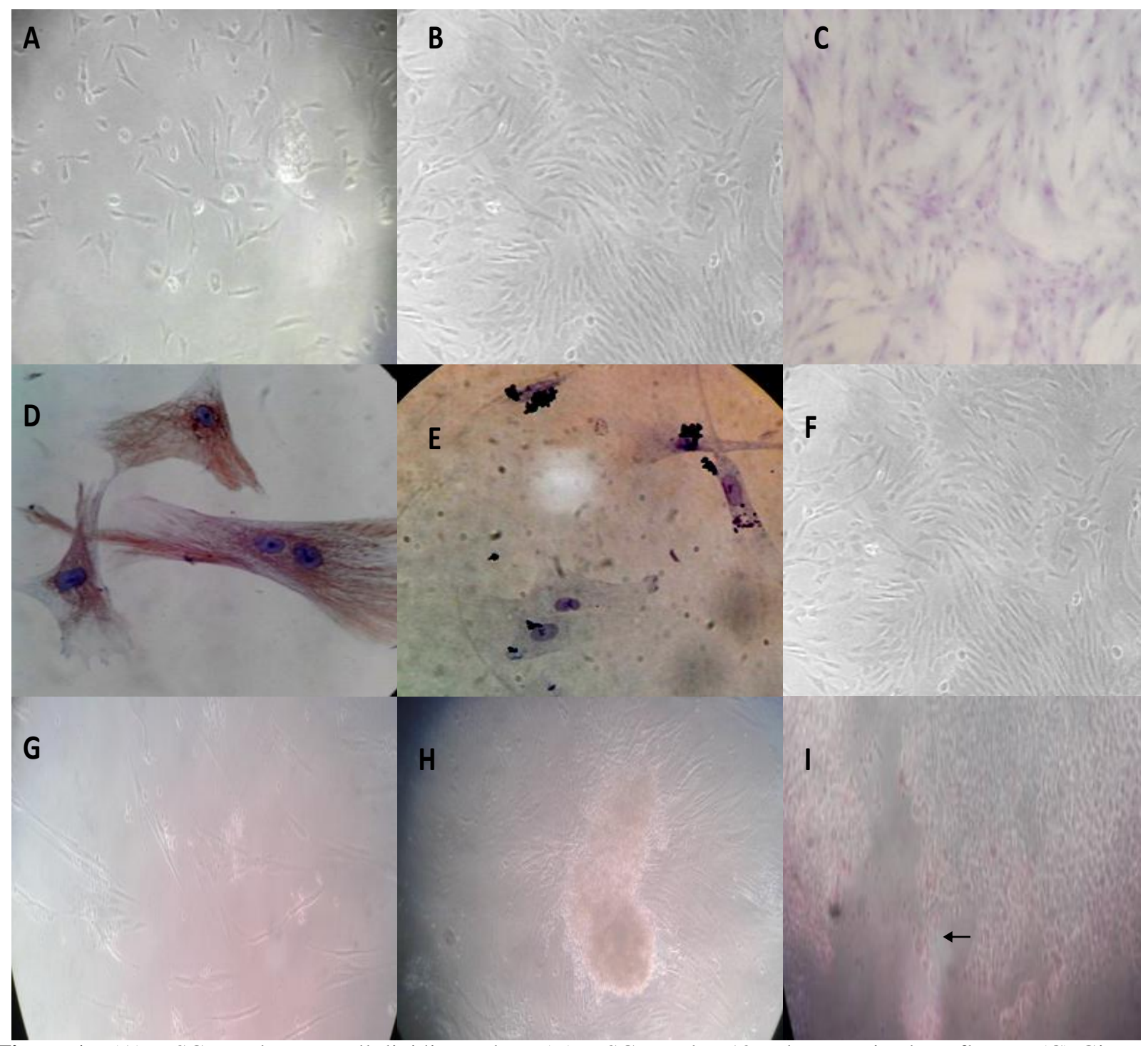

Figure 1:- (A) MSCs on day-6-small dividing colony (B) MSCs on day-12-colony attained confluency (C) Giemsa staining-Fibroblastic appearance of MSCs and its colony forming capacity. IHC: (D) Immunocytochemical staining- MSCs expressing Vimentin, which is one of the positive markers, (E) Negative control- Cells stained without Vimentin antibody. Differentiation: (F) MSCs showing 80\% cell confluency on day 1 of differentiation (G) Day 2 of differentiation (H) Day 15 of differentiation-cells aggregated in clusters (I) At the end of differentiation (25 days) cells stained positive for DTZ stain. 

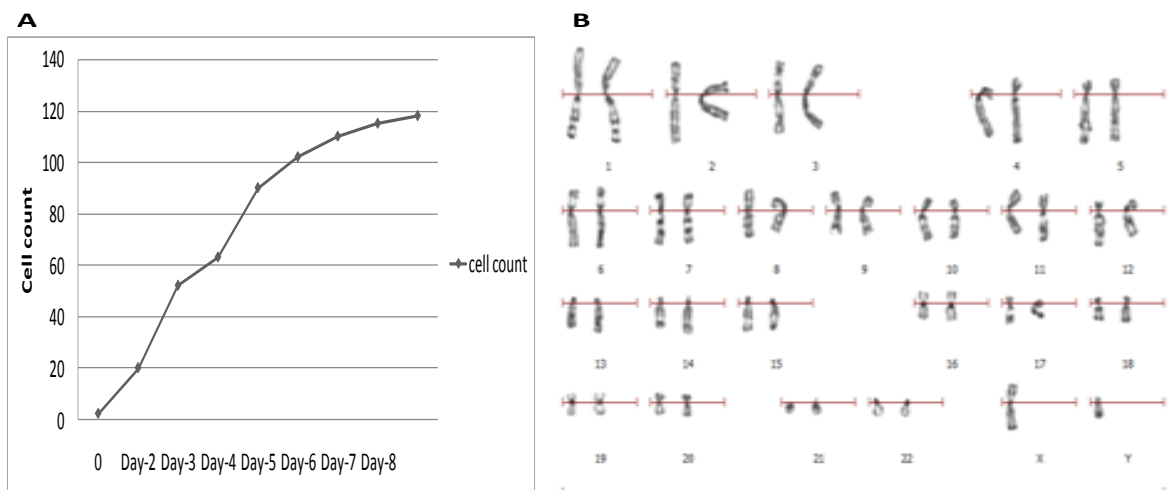

Figure 2:- (A) Growth curve- After day-5 cell senescence was observed. (B) Karyotyping- Genome integrity was observed till the last passage (passage-5).

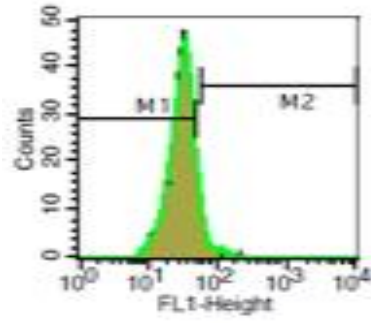

A

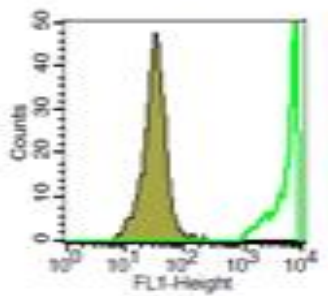

D

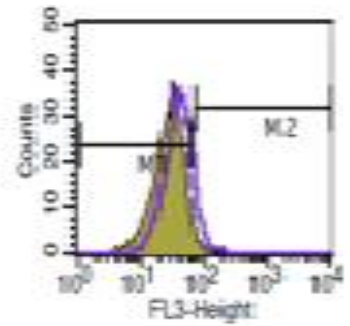

B

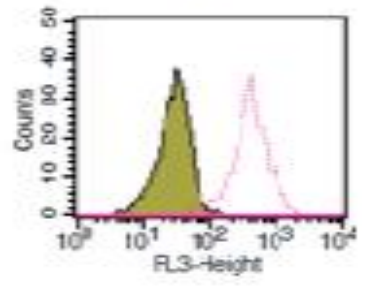

E

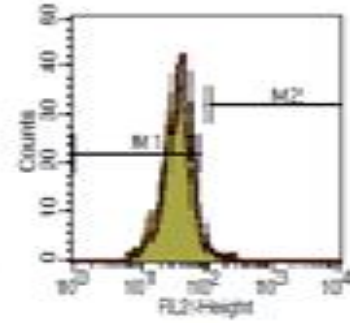

$\mathrm{C}$

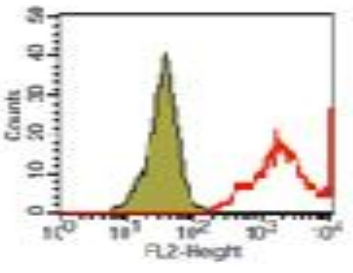

$\mathrm{F}$

Figure 3:- Flowcytometry analysis- (A) CD34, 0\%; (B) CD45, 0\%; (C) HLA-DR, 10\%; (D) CD90, 95\%; (E)CD105,95\%;(F)CD73,80\%; (CD34,CD45-Haematopoitic stem cell marker, CD90, CD73,CD105-Mesenchymal stem cell markers and HLA-DR is an MHC class II cell surface receptor ).

\section{Discussion:-}

Diabetes is a group of disorders in which defective insulin production or function results in the deregulation of blood glucose levels. T1D and T2D are the most common forms of Diabetes. Irrespective of the etiology of diabetes the disorder is being diagnosed at an alarming rate and has been declared as a global epidemic by WHO, 2016. The disease burden and the complications associated with this progressive pathology is responsible for major morbidity and mortality causing both social and economic burden to developed and more so to developing countries. Given that diabetes is identified in both rural and urban populations in India, there is an urgent need for intervention at regional and national levels to mitigate the potentially catastrophic health complications [21]. Apart from life style modifications, several categories of drugs are available for managing diabetic patients and to delay the associated complications [22]. Recombinant insulin production revolutionized diabetic therapy especially for T1D [23, 24]. There are conflicting reports regarding the benefits of early insulin treatment in T2D [25]. 
Since Insulin replacement partially carries out, but does not match the precision of functioning $\beta$-cells, total pancreatic transplant surgery was considered as an option in 2000 [26]. However, there are several drawbacks to this approach which include: (i) mortality rate associated with the surgery, (ii) lifelong immunosuppression associated with adverse health effects and (iii) limited availability of donor pancreases [27]. Hence, human islet fetal transplant was considered as another alternative as they have a better self renewable capacity and can differentiate into pancreatic endocrine cells. However, inconsistencies in the islet yield, short term success rates and ethical issues restricted this treatment modality [2].

More recently stem cell therapy is an attractive alternative for the treatment of several diseases including Diabetes. Adult autologous Stem cells can be extracted from different parts of the body [28]. In the present study umbilical cord tissue which is usually considered as a clinical waste and discarded after the delivery of the baby was used. UC is easily accessible, available source of MSCs without ethical conflicts [19, 29].

For more than a decade several researchers are working on developing pancreatic islet insulin expressing cells from cord blood/tissue for use in the treatment of diabetes [8,30]. In a country like India, with an estimated birth rate of 21.8 per 1000 people would be one of the largest sources of umbilical cord tissue to isolate MSCs in the world [31].

Present study indicated that collecting UC tissue after LSCS from the operation theatre gives better culturable MSCs when compared to vaginal deliveries, when the same number of samples were collected from each mode of delivery $(\mathrm{n}=12)$. This is the first time to the best of our knowledge that this aspect has been evaluated. Since there were contradictions about the method of isolating MSCs, some studies have described disadvantages with enzymatic method such as yield, cost, contamination and process time [32,33], while others supported enzyme digestion over mechanical method [34]. Hence, we used a combination of both mechanical and enzymatic methods. It gave us an yield of $1.5^{*} 10^{5} \pm 0.5 * 10^{5} \mathrm{cells} / 8 \mathrm{~cm}$ of UC after 12 days of processing (Figure 1 ). These numbers were relatively low when compared to reports from other groups $[17,35]$ and may be due to the variation in the initial quantity of the cord tissue used.

In the present investigation, growth curves indicated that MSCs, reached a 70-80\% confluency, on day five when 2000 cells $/ \mathrm{cm}^{2}$ were seeded for $\mathrm{P}^{1}$ population and karyotyping did not show any structural and/or numerical abnormalities in the cells cultured in-vitro till the $5^{\text {th }}$ passage Based on these results we performed differentiation after the $2^{\text {nd }}$ passage (Figure $2(A \& B)$ ).

Based on published studies CD-73, CD-90, CD-105, Vimentin, CD-34, CD-45 and HLA-DR markers were used to characterize the MSCs. In the present study 95\% of undifferentiated cells expressed CD-73, CD-90, CD105 ,Vimentin, none of the cells expressed CD-34, CD-45 and low expression was observed for HLA-DR after the second passage, confirming that these are MSCs. (Figure 3), which is similar to other published reports [14,36].

Different protocols have been published to differentiate HUMSCs into insulin producing $\beta$-cells in-vitro [8]. Wang et.al (2011), had earlier differentiated HUCMSCs into pancreatic $\beta$-cells using H-DMEM (25mM glucose/L), $\beta$ Mercaptoethanol $(0.1 \mathrm{mM})$, b-Fibroblast growth factor $(10 \mu \mathrm{g} / \mathrm{L})$ and Nicotinamide $(10 \mathrm{mM} / \mathrm{L})$. We achieved similar results after 25 days of incubation by additionally adding Taurine as it was shown to be an efficient endodermal differentiation factor [19]. Under the above conditions only some of the HUMSCs differentiated into insulinproducing cells which released insulin on glucose stimulation, which might represent $\beta$-cells and stained positive with Dithizone which is an islet specific stain (Figure 1).

\section{Conclusion:-}

It is evident from this study that HUMSCs have a potential to differentiate into insulin secreting $\beta$-cell in-vitro. Efficient differentiation protocol and suitable homing methods would help in translating the technology from laboratory bench to the clinic in near future to treat DM.

\section{Acknowledgements:-}

We are thankful to our host institute, Kamineni Hospitals for providing infrastructure and necessary equipment to carry out our experimental work. We are grateful to all our patients who participated in this study. We are thankful to the Department of Genetics, Osmania University. We thank all the staff members for their cooperation and 
technical assistance. Special thanks to Department of Science and Technology (DST) India, for providing JRF Inspire fellowship.

\section{Funding Sources:-}

This research did not receive any other grant from other funding agencies apart from DST inspire fellowship in the public, commercial, or not-for-profit sectors. DST had no role in study design, data collection and analysis, decision to publish, or preparation of the manuscript.

\section{Conflict of interest:-}

Authors declare no conflict of interest.

\section{References:-}

1. Skyler JS, Ricordi C. Stopping type 1 diabetes: attempts to prevent or cure type 1 diabetes in man. Diabetes. 2011 Jan 1;60(1):1-8.

2. Krishnan R, Alexander M, Robles L, Foster 3rd CE, Lakey JR. Islet and stem cell encapsulation for clinical transplantation. Rev Diabet Stud. 2014;11(1):84-101.

3. Dooley J, Tian L, Schonefeldt S, Delghingaro-Augusto V, Garcia-Perez JE, Pasciuto E, Di Marino D, Carr EJ, Oskolkov N, Lyssenko V, Franckaert D. Genetic predisposition for beta cell fragility underlies type 1 and type 2 diabetes. Nature genetics. 2016 Mar 21.

4. Oliver-Krasinski JM, Stoffers DA. On the origin of the $\beta$ cell. Genes \& development. 2008 Aug 1;22(15):19982021.

5. Gabr MM, Zakaria MM, Refaie AF, Khater SM, Ashamallah SA, Ismail AM, El-Badri N, Ghoneim MA. Generation of insulin-producing cells from human bone marrow-derived mesenchymal stem cells: comparison of three differentiation protocols. BioMed research international. 2014 Apr 10;2014.

6. Miranda PM, Mohan V, Ganthimathy S, Anjana RM, Gunasekaran S, Thiagarajan V, Churchill TA, Kin T, Shapiro AJ, Lakey JR. Human islet mass, morphology, and survival after cryopreservation using the Edmonton protocol. Islets. 2013 Sep 13;5(5):188-95.

7. Liao YH, Verchere CB, Warnock GL. Adult stem or progenitor cells in treatment for type 1 diabetes: current progress. Canadian journal of surgery. 2007 Apr 1;50(2):137.

8. Anzalone R, Iacono ML, Loria T, Di Stefano A, Giannuzzi P, Farina F, La Rocca G. Wharton's jelly mesenchymal stem cells as candidates for beta cells regeneration: extending the differentiative and immunomodulatory benefits of adult mesenchymal stem cells for the treatment of type 1 diabetes. Stem Cell Reviews and Reports. 2011 Jun 1;7(2):342-63.

9. Wang HW, Lin LM, He HY, You F, Li WZ, Huang TH, Ma GX, Ma L. Human umbilical cord mesenchymal stem cells derived from Wharton's jelly differentiate into insulin-producing cells in vitro. Chinese Medical Journal-Beijing. 2011 May;124(10):1534.

10. Buder B, Alexander M, Krishnan R, Chapman DW, Lakey JR. Encapsulated islet transplantation: strategies and clinical trials. Immune network. 2013 Dec 1;13(6):235-9.

11. Schmidt C. Pancreatic islets find a new transplant home in the omentum.

12. Fazzina R, Iudicone P, Fioravanti D, Bonanno G, Totta P, Zizzari IG, Pierelli L. Potency testing of mesenchymal stromal cell growth expanded in human platelet lysate from different human tissues. Stem cell research \& therapy. 2016 Aug 25;7(1):122.

13. Mennan C, Wright K, Bhattacharjee A, Balain B, Richardson J, Roberts S. Isolation and characterisation of mesenchymal stem cells from different regions of the human umbilical cord. BioMed research international. 2013 Jul 25;2013.

14. Feisst V, Brooks AE, Chen CJ, Dunbar PR. Characterization of mesenchymal progenitor cell populations directly derived from human dermis. Stem cells and development. 2013 Dec 10;23(6):631-42.

15. Park JR, Kim E, Yang J, Lee H, Hong SH, Woo HM, Park SM, Na S, Yang SR. Isolation of human dermis derived mesenchymal stem cells using explants culture method: expansion and phenotypical characterization. Cell and tissue banking. 2015 Jun 1;16(2):209-18.

16. Troyer DL, Weiss ML. Concise review: Wharton's Jelly-derived cells are a primitive stromal cell population. Stem cells. 2008 Mar 1;26(3):591-9.

17. Yoon JH, Roh EY, Shin S, Jung NH, Song EY, Chang JY, Kim BJ, Jeon HW. Comparison of explant-derived and enzymatic digestion-derived MSCs and the growth factors from Wharton's jelly. BioMed research international. 2013 Apr 9;2013. 
18. Chen G, Yue A, Ruan Z, Yin Y, Wang R, Ren Y, Zhu L. Comparison of biological characteristics of mesenchymal stem cells derived from maternal-origin placenta and Wharton's jelly. Stem cell research \& therapy. 2015 Nov 25;6(1):228.

19. Kadam SS, Bhonde RR. Islet neogenesis from the constitutively nestin expressing human umbilical cord matrix derived mesenchymal stem cells. Islets. 2010 Mar 1;2(2):112-20.

20. Chao KC, Chao KF, Fu YS, Liu SH. Islet-like clusters derived from mesenchymal stem cells in Wharton's Jelly of the human umbilical cord for transplantation to control type 1 diabetes. PloS one. 2008 Jan 16;3(1):e1451.

21. Kaveeshwar SA, Cornwall J. The current state of diabetes mellitus in India. The Australasian medical journal. 2014;7(1):45.

22. Kalra S, Zargar AH, Jain SM, Sethi B, Chowdhury S, Singh AK, Thomas N, Unnikrishnan AG, Thakkar PB, Malve H. Diabetes insipidus: The other diabetes. Indian journal of endocrinology and metabolism. 2016 Jan;20(1):9.

23. Moncrieft AE, Llabre MM, McCalla JR, Gutt M, Mendez AJ, Gellman MD, Goldberg RB, Schneiderman N. Effects of a Multicomponent Life-Style Intervention on Weight, Glycemic Control, Depressive Symptoms, and Renal Function in Low-Income, Minority Patients With Type 2 Diabetes: Results of the Community Approach to Lifestyle Modification for Diabetes Randomized Controlled Trial. Psychosomatic Medicine. 2016 Sep;78(7):851.

24. Asaad G, Soria-Contreras DC, Bell RC, Chan CB. Effectiveness of a Lifestyle Intervention in Patients with Type 2 Diabetes: The Physical Activity and Nutrition for Diabetes in Alberta (PANDA) Trial. InHealthcare 2016 Sep 27 (Vol. 4, No. 4, p. 73). Multidisciplinary Digital Publishing Institute.

25. Munnee K, Bundhun PK, Quan H, Tang Z. Comparing the Clinical Outcomes Between Insulin-treated and Non-insulin-treated Patients With Type 2 Diabetes Mellitus After Coronary Artery Bypass Surgery: A Systematic Review and Meta-analysis. Medicine. 2016 Mar;95(10).

26. Yeh CC, Spaggiari M, Tzvetanov I, Oberholzer J. Robotic paneb;96(6).creas transplantation in a type 1 diabetic patient with morbid obesity: A case report. Medicine. $2017 \mathrm{~F}$

27. Lilly MA, Davis MF, Fabie JE, Terhune EB, Gallicano GI. Current stem cell based therapies in diabetes. American Journal of Stem Cells. 2016;5(3):87.

28. Alix HA, PARK JC. Dental Stem Cells and Their Applications. Chin J Dent Res. 2015;18(4):207-12.

29. Gao F, Chiu SM, Motan DA, Zhang Z, Chen L, Ji HL, Tse HF, Fu QL, Lian Q. Mesenchymal stem cells and immunomodulation: current status and future prospects. Cell death \& disease. 2016 Jan 1;7(1):e2062.

30. Forraz N, McGuckin CP. The umbilical cord: a rich and ethical stem cell source to advance regenerative medicine. Cell Proliferation. 2011 Apr 1;44(s1):60-9.

31. Verma V1, Tabassum N1, Yadav C.B, Kumar M, Singh A.K, Singh M.P, Kumar A, Singh B and Gautam S.K. Cord Blood Banking: An Indian Perspective. Cell Mol Biol 2016,62:3.

32. Hendijani F, Sadeghi-Aliabadi H, Javanmard SH. Comparison of human mesenchymal stem cells isolated by explant culture method from entire umbilical cord and Wharton's jelly matrix. Cell and tissue banking. 2014 Dec 1;15(4):555-65.

33. Iftimia-Mander A, Hourd P, Dainty R, Thomas RJ. Mesenchymal stem cell isolation from human umbilical cord tissue: understanding and minimizing variability in cell yield for process optimization. Biopreservation and biobanking. 2013 Oct 1;11(5):291-8.

34. Claudia G, Walter B, Janina B, Henriette J, Carsten S, Iris Ribitsch. Isolation of equine multipotent mesenchymalstromal cells by enzymatic tissue digestion or explant technique: comparison of cellular properties. BMC Veterinary Research. 2013,9:221.

35. Tong CK, Vellasamy S, Tan BC, Abdullah M, Vidyadaran S, Seow HF, Ramasamy R. Generation of mesenchymal stem cell from human umbilical cord tissue using a combination enzymatic and mechanical disassociation method. Cell biology international. 2011 Mar 1;35(3):221-6.

36. Marmotti A, Mattia S, Bruzzone M, Buttiglieri S, Risso A, Bonasia DE, Blonna D, Castoldi F, Rossi R, Zanini C, Ercole E. Minced umbilical cord fragments as a source of cells for orthopaedic tissue engineering: an in vitro study. Stem cells international. 2012 Mar 7;2012. 